症例

\title{
肋骨転移をきたした $\mathrm{T} 1 \mathrm{~b}$ 直腸癌の 1 例
}

\author{
JCHO 大阪病院外科 ${ }^{1)}$, 同 病理科 ${ }^{2)}$ \\ 河 野 恵美子 1) 山崎 芳 郎1) 安 政 啓 吾1) 春日井 務
}

62歳，女性．検診で便潜血陽性を指摘され，当科に紹介となった，大腸内視鏡検査に て下部直腸に $10 \mathrm{~mm}$ 大の I sp型腫瘍を認め, 内視鏡的粘膜切除術を施行した．tub1, T1b $(2,000 \mu \mathrm{m})$, ly0, v1, budding grade1, HM0 $(250 \mu \mathrm{m})$, VM0 $(500 \mu \mathrm{m})$ であり, 腹腔鏡補助下低位前方切除術 $+\mathrm{D} 2$ 郭清術を施行した，病理組織学的に腫瘍の遺残は認 めず，総合所見はT1b，N0，M0，Stage Iであった，術後 6 カ月のCT検查で両側第 9 肋骨に腫瘤を指摘され, FDG-PET検査を施行したところ, 異常集積（SUVmax7.8）を 認めた．CTガイド下生検を施行したところ高分化管状腺癌であり，直腸癌の転移と診 断した. 早期直腸癌術後で肝臟や肺転移を伴わない骨転移は稀であり, 文献的考察を加 え報告する。

索引用語：早期直腸癌, 骨転移, 腹腔鏡補助下手術

はじめに

大腸癌の骨転移の頻度は $5 \sim 6 \%$ と稀であり ${ }^{1)}$, 肺 や肝など他藏器の転移を合併していることが多い。今 回われわれは, $10 \mathrm{~mm}$ 大の早期直腸癌の術後半年で両 側肋骨に転移をきたした 1 例を経験したので報告す る.

\section{症例}

患者：62歳, 女性.

主訴：便潜血陽性.

既往歴：35歳時, 左乳癌にて手術.

家族歴：父親が胃癌.

現病歴：平成 24 年 2 月に検診で便潜血陽性を指摘さ れ，4月に精査目的で当院に紹介となった。

入院時現症：身長 $149 \mathrm{~cm}$, 体重 $52 \mathrm{~kg}$. 腹部は平坦・ 軟・圧痛なし，直腸診では腫瘤は触知せず。

入院時血液検査所見 : 血液生化学所見に異常を認め なかった. 血中腫瘍マーカーはCEA $1 \mathrm{ng} / \mathrm{ml}, \mathrm{CA} 19-9$ $2 \mathrm{ng} / \mathrm{ml}$ 未満と正常值を示した.

大腸内視鏡検査所見：下部直腸（Rb）に $10 \mathrm{~mm} の$ I sp型腫瘍を認め, 内視鏡的粘膜切除術 (endoscopic mucosal resection：EMR）を施行した（Fig. 1).

2017 年 3 月 10 日受付 2017 年 3 月 23 日採用

〈所属施設住所〉

于553-0003 大阪市福島区福島 4-2-78
病理組織学的所見 : 高分化型の管状腺癌を認めた. 粘膜筋板下縁から $2,000 \mu \mathrm{m}$ の粘膜下層に浸潤する腫 瘍細胞を認めた.リンパ管浸潤は認めなかったが, 静 脈浸潤を認めた。浸潤先進部の簇出（budding）は Grade1 であった，水平断端と垂直断端は院性であっ た (Fig. 2).

注腸検査所見：直腸にEMR後のクリップ (○印) を認めた（Fig. 3).

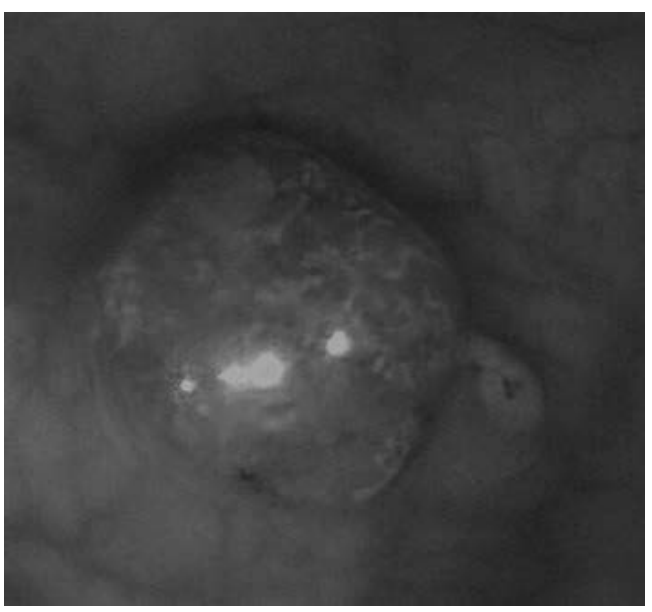

Fig. 1 大腸内視鏡検査 : 上部直腸に $10 \mathrm{~mm}$ 大の I sp 型腫瘍を認めた. 


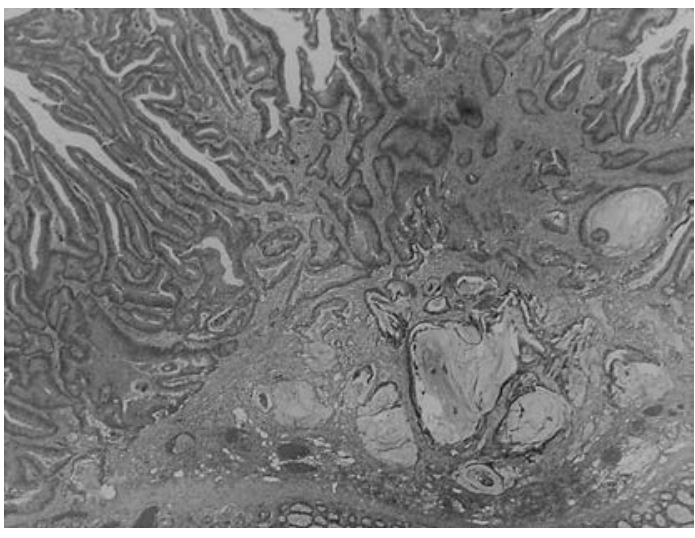

Fig. 2 病理組織学的検査（H.E.染色 $\times 40 ） ：$ 高分化管状 腺癌を認めた。粘膜筋板下縁から $2,000 \mu \mathrm{m}$ の粘膜下層 まで浸潤していた。静脈浸潤を認めた。

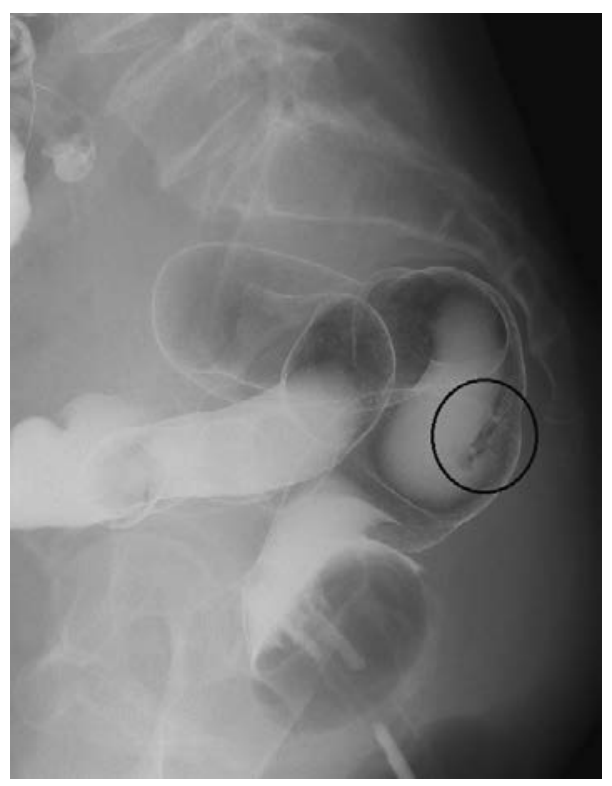

Fig. 3 注腸検査所見：上部直腸に EMR後のク リップを認めた（○印).

腹部造影CT検査所見：明らかな転移は認めなかっ た。

手術所見：上記の結果から, pT1（SM）直腸癌の 追加治療の適応と診断し, 腹腔鏡補助下低位前方切除 術 +D2郭清術を施行した。

切除標本肉眼所見: EMR後の㓔痕を認めるのみで, 明らかな癌の遺残は認めなかった。

病理組織学的所見 : 癌の遺残は認めなかった.リン
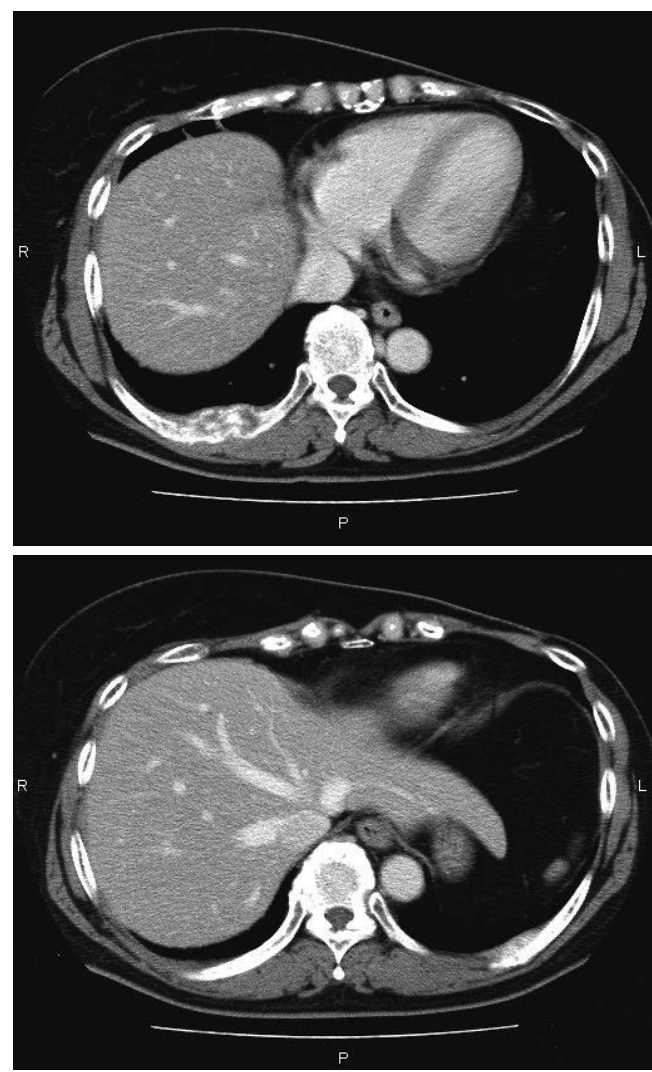

Fig. 4a, b 胸腹部 CT 検査所見: 右第 9 肋骨に腫瘤・ 骨破壞を認めた（a ）。左第 9 肋骨に腫瘤を認めた (矢印) (b).

$\frac{\mathrm{a}}{\mathrm{b}}$

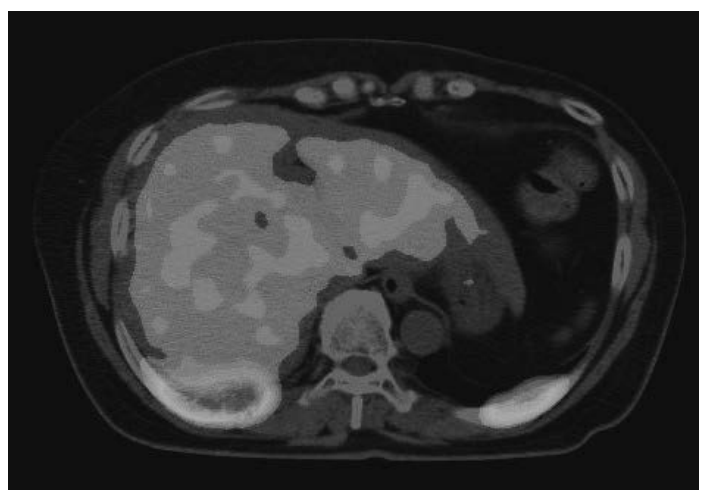

Fig. 5 FDG-PET 検査所見：両側第 9 肋骨に異常集積 (SUVmax7.8) を認めた. 


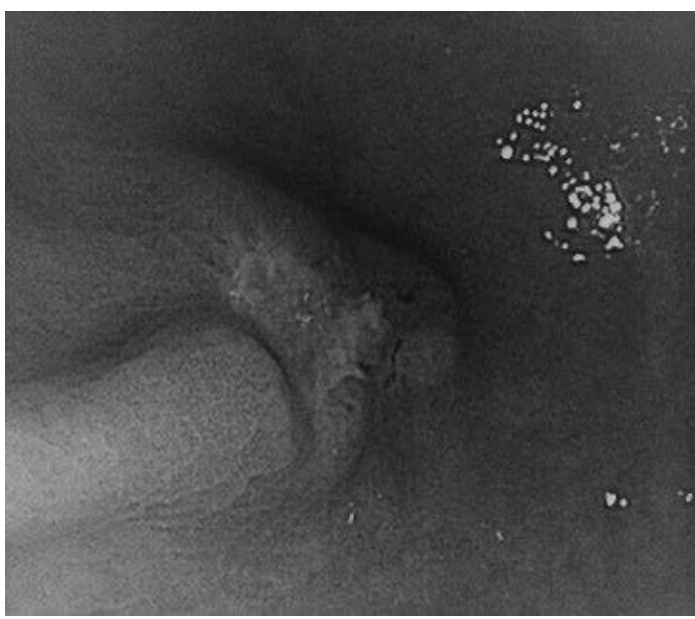

Fig. 6 上部消化管内視鏡検査所見：胃角部大網に $10 \mathrm{~mm}$ 大の 0 - II c 型腫瘍を認めた

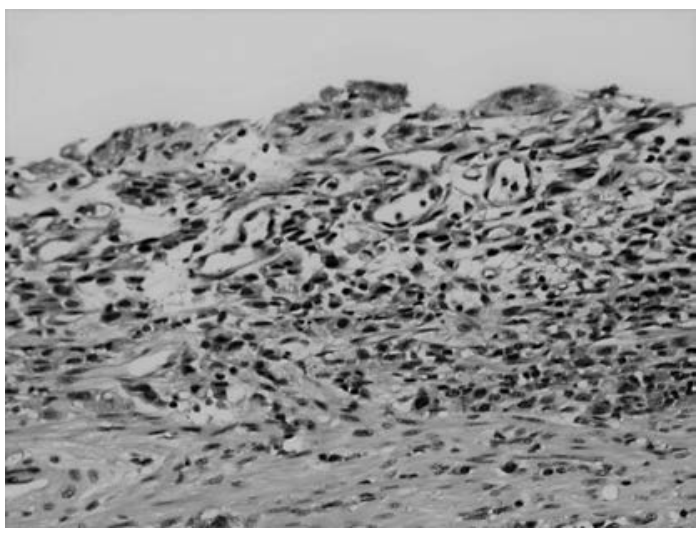

Fig. 7 病理組織学的検査 $($ H.E. 染色 $\times 100)$ : 粘膜下層 に広範に浸潤する低分化腺癌を認めた。

パ節にも転移を認めなかった。

術後経過：概ね良好で12日目に退院した。

Stage I であり外来で経過観察していたが, 術後 6 カ月の CEAが $17.0 \mathrm{ng} / \mathrm{ml}$ と上昇し, CT検査で, 両側 第 9 肋骨に骨破壊像・腫瘤を認めた（Fig. 4a， b). FDG-PET 検査で同部位にのみ SUVmax7.8と異常集 積を認めた（Fig. 5). 胁骨転移の原因精査で行った 上部消化管内視鏡検查で胃角部に $10 \mathrm{~mm}$ 大の 0 - II c 病変を認め (Fig. 6), 病理組織学的検查では胃癌 (signet ring cell carcinoma)の診断であった(Fig. 7). 適応拡大病変の診断で $\mathrm{ESD}$ を施行し, 病理学的検索 では径 $15 \times 15 \mathrm{~mm}, 0-\mathrm{II}$ c, por2, pT1b $(1,400 \mu \mathrm{m})$,

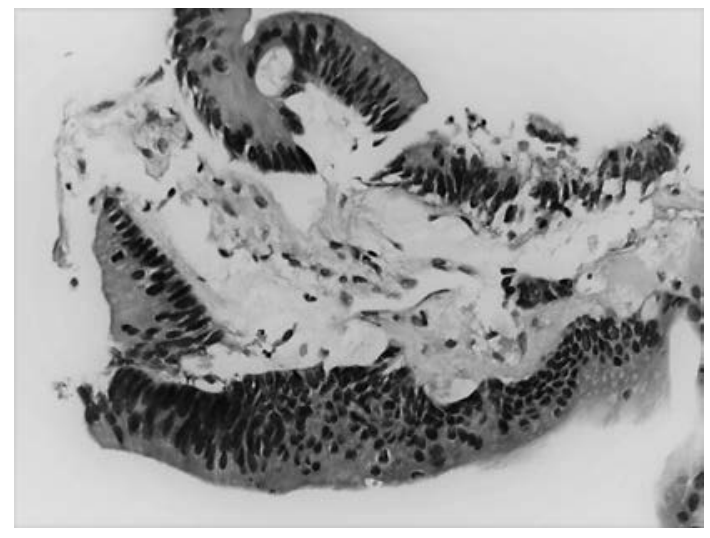

Fig. 8 病理組織学的検査（H.E.染色 $\times 200 ）$ : 好塩基性 の核を持つ腫瘍細胞の腺管形成があり，直腸癌の転移 として矛盾しない所見であった.

$\mathrm{ULs}(+), 1 \mathrm{y} 0, \mathrm{v} 0, \mathrm{pHM} 0, \mathrm{pVM} 0$ であった，乳癌の 既往もあり，原発巣を明らかにする目的でCTガイド 下生検を施行したところ，高分化管状腺癌であり，直 腸癌の骨転移と診断した (Fig. 8)。その後, 放射線 治療（合計36Gy/12fr）を行い，化学療法は一次治療 としてXELOX + bevacizumab 療法, 二次治療として FOLFIRI+ panitumumab 療法を施行したが，多発肺 転移・肝転移・脳転移が出現し, 術後 1 年 10 力月で死 亡した.

\section{考察}

大腸 SM 癌に対する外科手術の中・長期的成績は良 好であり，松田らの報告によると，疾患特異的 5 年生 存率はSM癌全体で $97.2 \%$ であったと報告されてい る ${ }^{2)}$. 大腸癌治療ガイドラインでは，SM癌の約 $10 \%$ にリンパ節転移があることから，内視鏡的摘除された $\mathrm{SM}$ 癌の追加治療の適応基準は，(1) SM 浸潤度 1,000 $\mu \mathrm{m}$ 以上，(2)脈管侵襲陽性，(3)低分化腺癌，印環細胞 癌, 粘液癌, (4) 浸潤先進部の簇出 (budding) Grade2 / 3 とされ, 郭清範囲は中間リンパ節転移も少 なくないことから D2 郭清が必要とされている3). 自 験例は，(1)と(2)を満たしているため追加切除が必要と 判断し, 腹腔鏡補助下低位前方切除術 $+\mathrm{D} 2$ 郭清術を 行った.

大腸癌の骨転移の頻度は剖検例で $8.6 \sim 27 \%$, 臨床 症例で3.7〜 11\%と低い4). 骨転移をきたしている場合, 肝臟や肺に転移を伴っていることが多く，自験例のよ うな骨転移単独例は少ない(1)5).

医学中央雑誌で「大腸癌」「骨転移」をキーワード 
として1983年～2016年12月で検索しえた症例数（会議 録は除く）は，37例であったささらに，早期癌となる と自験例を含む 4 例のみであった $(\text { Table 1 })^{6) \sim 8)}$.

松田らは, 大腸 SM 癌193例の外科手術の中・長期 成績の検討をしており，有意な再発リスク因子は $\mathrm{Rb}$ のみであり, $\mathrm{Rb}$ 癌の術後は慎重なフォローアップを 要すると述べている2). 骨転移をきたした早期大腸癌 4 例の腫瘍の局在は全て下部直腸（Rb）であった.

Jimi らは大腸癌骨転移の診断にCEAが有用であり, 88\%の症例でCEA 上昇を認めたと述べている ${ }^{4)}$, 自験 例含め全例でCEAの上昇をきたし，その後骨転移の 診断に至っている. 側方リンパ節転移再発が先行し, 切除した後に骨転移をきたした症例が 2 例，側方リン パ節転移と骨転移を同時にきたした症例が 1 例であっ た，骨転移が先行した症例は自験例のみであった。

骨転移をきたした大腸癌症例の予後は不良であり， 骨転移と診断されてからの生存期間中央值は約 7 カ月 と報告されている ${ }^{9)}$. 骨転移に対する治療は化学療法 や放射線治療が選択されることが多く，孤立性骨転移 で根治的切除が行える症例は稀である ${ }^{10)}$. 骨転移をき たした早期大腸癌 4 例も孤立性転移はなく, 予後不良 であった。

自験例は早期胃癌を併存しており，予後規定因子が 胃癌であった可能性は完全に否定できない.しかし, 早期胃癌の肝転移の頻度は $1 \%$ 前後といわれてお $り^{11)}$, 関連性は低いと思われる。異時性肺転移の本邦 報告例は井上らの報告のみであり ${ }^{12)}$, さらに脳への単 独の転移となると報告はない，以上より，胃癌の肝転 移・肺転移・脳転移の可能性は極めて低いと判断した.

一般的に大腸 SM癌の予後は良好だが, 自験例のよ うにStage Iであっても早期に再発し死に至ることも ある。

従って, 大腸 SM癌であっても再発のリスクがある ことを念頭に置き，フォローアップを行うことが肝要 である。

\section{結 語}

早期直腸癌の術後に肋骨転移をきたした稀な 1 例を 経験したので, 若干の文献的考察を加えて報告した.

利益相反：なし

\section{文 献}

1) Kanthan R, Loewy J, Kanthan SC : Skeletal metastasis in colorectal carcinomas. Dis Colon Rectum $1999 ; 42: 1592-1597$ 
2）松田圭二, 塚本充雄, 福島慶久他：大腸 SM（T1） 癌に対する外科手術の中 · 長期成績. 胃と腸 $2015 ; 50: 426-436$

3）大腸癌研究会/編：大腸癌治療ガイドライン一医 師用2016年版. 金原出版, 東京, 2016, p52-53

4) Jimi S, Yasui T, Hotokezaka M, et al : Clinical features and prognostic factors of bone metastases from colorectal cancer. Surg Today 2013 ; $43: 751-756$

5) Beak SJ, Hur H, Min BS, et al : The Characteristics of Bone Metatastasis in Patients with Colorectal Cancer : A Long-Term Report from a Single Institution. World J Surg 2016 ; 40 : 982 $-986$

6）中㠃隆行，演嵪景子：多発性骨転移を来した直腸 $\mathrm{SM}$ 癌の 1 例. 日本大腸肛門病会誌 $2009 ; 62$ : $411-415$

7）山下晋也，池田正孝，金 浩敏他：直腸 $\mathrm{SM}$ 癌で側 方リンパ節再発を来した 1 例．癌と化療 2010 ；
$37: 2629-2631$

8）岩本一亜, 荒木靖三, 野明俊裕他：側方領域再発 切除後急激に骨・肝再発した直腸 SM癌の 1 例. 日臨外会誌 $2014 ; 75: 2509-2513$

9) Santini D, Tampellini M, Vincenzil B, et al : Natural history of bone metastasis in colorectal cancer : final results of a large Italian bone metastases. Ann Oncol $2012 ; 23: 2072-2077$

10）飯野 弥, 森 義之, 三井文彦他 : 外科的切除に より長期生存となった坐骨転移をともなう直腸癌 の 1 例. 日本大腸肛門病会誌 $2010 ; 63: 660-$ 667

11）柳澤 暁, 佐野芳史, 岡本友好他：長期生存が得ら れた早期胃癌肝転移の 1 例。日臨外会誌 2003 ； $64: 1217-1220$

12）井上陽一, 城戸哲夫, 田中康博他： 2 度の肺転移 切除後長期生存が得られている早期胃癌の 1 例. 日臨外会誌 $2002 ； 63: 52-55$

\title{
A CASE OF EARLY RECTAL CARCINOMA WITH METASTASES TO THE RIBS AFTER LAPAROSCOPIC-ASSISTED LOW ANTERIOR RESECTION
}

\author{
Emiko KONO ${ }^{1)}$, Yoshio YAMASAKI ${ }^{1)}$, Keigo YASUMASA ${ }^{1)}$ and Tsutomu KASUGAI ${ }^{2)}$ \\ Departments of Surgery ${ }^{1}$ and Pathology ${ }^{2}$, Japan Community Health Care Organization Osaka Hospital
}

A 62-year-old woman whose occult blood test was positive at a medical checkup was referred to our department. Colonoscopy revealed a 10-mm sized type Isp tumor in the lower rectum, We performed endoscopic mucosal resection that revealed the tumor as tub1, T1b $(2,000 \mu \mathrm{m})$, ly0, v1, budding grade 1 , HM0 $(250 \mu \mathrm{m})$, and VM0 $(500 \mu \mathrm{m})$. Laparoscopic-assisted low anterior resection of the rectum + D2 dissection was performed. Histopathology revealed no tumor remnant, showing T1b, N0, M0, and Stage I . A CT scan performed 6 months after the operation demonstrated tumors at the bilateral ninth limbs. FDGPET scan showed abnormal accumulation of FDG (SUVmax7.8) to the tumors. CT-guided biopsy identified the tumors to be well differentiated tubular adenocarcinoma, and metastases of rectal cancer to the ribs were diagnosed.

As bone metastasis from early rectal cancer without associating with liver or pulmonary metastasis is rare, this case is presented, together with a review of the literature.

Key words : early rectal cancer, bone metastases, laparoscopic-assisted surgery 